\title{
ビフェニルー(フェニル- $\left.{ }^{14} \mathrm{C}\right)$ の合成 \\ 神山弘章*, 森川尚威**, 右田俊彦**, 伊藤良一**, 土橋源一* \\ ( $*$ 日本原子力研究所放射線応用部, ${ }^{* *}$ 東京大学理学部化学教室) \\ (昭和 35 年 4 月 22 日 受理)
}

\section{緒言}

有機減速材として最近ビフェニル，ターフェニ ルなどの物質が用いられているが，筆者らはビフ ェニルの放射線分解機構の研究に用いる目的でビ $フ_{x}$ ニルー (フェニル- $\left.{ }^{14} \mathrm{C}\right)$ を合成した。

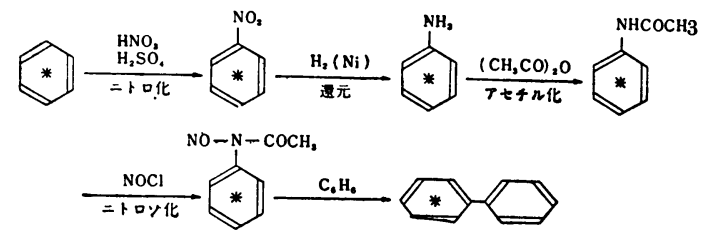

$5 \mathrm{~m} \mathrm{~mol} \mathrm{とする。}$

ニトロ化はすでに発表された文献のと同様な条 件で行なった。のちの還元の収率を $100 \%$ と仮定 すればニトロ化の収率は $84.2 \%$ 以上（予備実験そ のほかでは 84, 86, 92,106\%など)である。

2. アニリン $-{ }^{14} \mathrm{C}$ の合成

$200 \mathrm{ml}$ の共通すり合わせガラス容器に新らた に調製したラネーニッケル7 $2 \mathrm{ml}$ を入れ, さらに エタノール $20 \mathrm{ml}$ を加え,これを常圧接触還元装 置に接続し, 容器中の空気を水素と置換し, 電磁 式かきまぜ機を動かして触媒に水素を完全に吸収 させる。つぎに 1 で合成したニトロベンゼン- ${ }^{14} \mathrm{C}$

ビフェニルの合成法にはベンゼンの 熱分解1), ウルマン反応 ${ }^{2}$, グリニャー ル試薬と八ロゲン化ベンゼンの反応 ${ }^{3}$, ゴンベルグの反応)，フルオルベンゼ ンとフェニルリチウムとの反応b)など があるが収量のよいこと，合成のしや すいことなどの点を考慮してつぎの合 成方法を採用した。

各段階はあらかじめ無標識化合物で 同一規模の予備実験を行なって反応条 件，収率，純度などを確かめたのち本 合成を行なった。

\section{実験}

1. ニトロベンゼン- ${ }^{14} \mathrm{C}$ の合成

出発物質として The Radiochemical Centre, Amersham のベンゼン-1-14 $\mathrm{C} 1.0 \mathrm{mc}, 13.2 \mathrm{mg}$ を用いた。これに第 1 図に示すような装置で無標 識のベンゼン $378.5 \mathrm{mg}$ を加えて希釈し全量を

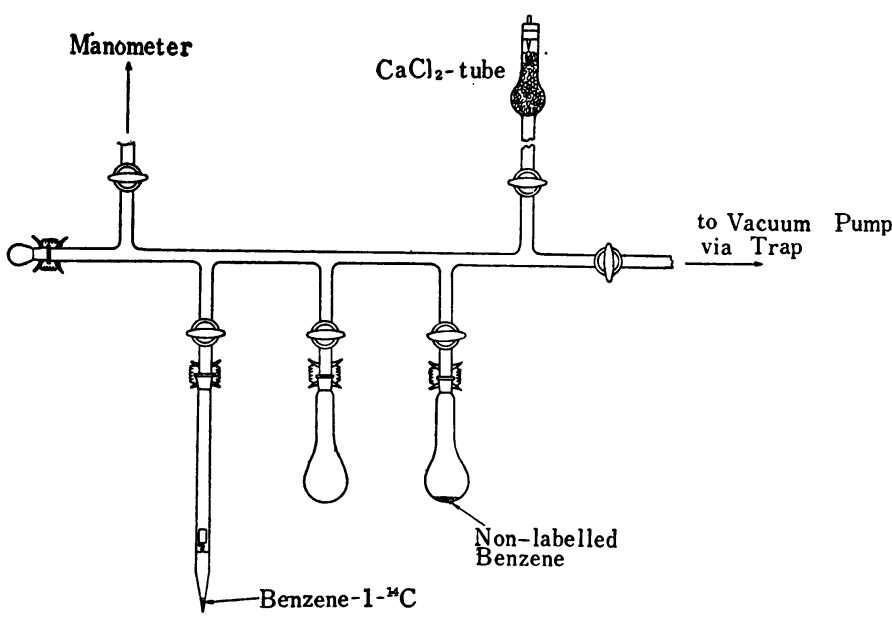

Fig. 1 Apparatus for Dilution of Benzene-1-14C

を $20 \mathrm{ml}$ のエタノールを用いて上記の還元容器 に移す。ふたたび容器中の空気を水素と置換しか きまぜながら水素を吸収させる。吸収が止まって からさらに約 10 分かきまぜを続ける。反応混合 物はソックスレーの固体抽出装置の円筒ロ紙に移 
し, 還元容器の器壁をエタノールで十分に洗浄し てこれに加え, エタノールで 1 時間抽出する。

3. アセトアニリドー(フェニル $\left.-{ }^{14} \mathrm{C}\right)$ の合成 2 で得た抽出液に無水酢酸 $1.1 \mathrm{~g}$ を加え常温で 一夜放置してアセチル化ののち水浴上でエタノー ルを留去する。これをエーテル中に調製した径 $28 \mathrm{~mm}$, 長さ $120 \mathrm{~mm}$ の活性アルミナ（和光純 薬製, $200 \mathrm{mesh}$ ) 柱を用い, エーテルを溶出液と してクロマトグラフ法で精製する。溶出したアセ トアニリド-(フェニル- $\left.{ }^{14} \mathrm{C}\right)$ を少量のエーテルで集 め, No. 3 グラスフィルターでロ過したのちエー テルを留去し一夜デシケーター中に放置する。収 量 $1028.9 \mathrm{mg}, 7.61 \mathrm{~m} \mathrm{~mol}$ 。アセチル化の収率は $82.6 \%$ (予備実験では 93 96\%)。この試料 2.180 $\mathrm{mg}$ に無標識アセトアニリド $996.8 \mathrm{mg}$ を加え, 水で再結晶を繰り返し再結晶 6 回目の前後のもの について Van Slyke-Folch の湿式酸化法 ${ }^{8}$ で酸 化し, 無限厚さの炭酸バリウム- ${ }^{14} \mathrm{C}$ として Tracerlab 社製のカーボンカウンターでその放射能 を測定した。計数の標準偏差が 1/100 以内になる 条件で測定したとき両者の值は一致したので放射 化学的に純粋になったものと考えられる。Tracerlab 社の炭酸バリウム $-{ }^{14} \mathrm{C} *$ を標準として比放 射能の算出を行なった結果は $87.7 \pm 0.9 \mathrm{mc} / \mathrm{mol}_{\text {。 }}$ ベンゼンよりアセトアニリドまでの放射化学的収 率は 66.7\%。

4. $\mathrm{N}-$ ニトロソアセトアニリド-(フェニル $\left.-{ }^{14} \mathrm{C}\right)$ の 合成

$30 \mathrm{ml}$ の三角フラスコにアセトアニリド-(フェ ニルー14 C) $742.4 \mathrm{~g}, 5.50 \mathrm{~m} \mathrm{~mol}$ をはかり取り, 融 解した酢酸カリウム $1.9 \mathrm{~g}$ をよく粉砕して加え, 酢酸, 無水酢酸の混合溶媒 $(7: 3) 3.4 \mathrm{~m} l$ を加え て水浴上で温め均一にとかす。これに五酸化リン を小スパーテルに 2 杯加えよくふりまぜてから氷 水で邻却する。一方ドライアイスで邻却した容器 中にある塩化ニトロシルー無水酢酸溶液* $2.2 \mathrm{ml}$ を手早くビュレットに移し, 前述の溶液中に滴下

* この比放射能は $22.6 \mathrm{dps} / \mathrm{mg}$ 。
する。滴下中は三角フラスコを氷水中でよくふり まぜる。約 20 分かかって滴下後時々ふりまぜな がら約 30 分氷水中に放置する。反応液は細かく 砕いた氷 $25 \mathrm{~g}$ 中に注入し淡黄色の $\mathrm{N}$-ニトロソア セトアニリドー(フェニル-14C) を析出させる。 5. ビフ $x$ ニル $\left(フ_{x}=ル-{ }^{14} \mathrm{C}\right)$ の合成

4 で合成した $\mathrm{N}$-ニトロソアセトアニリド-（フ ェニル $\left.-{ }^{14} \mathrm{C}\right)$ を約 $70 \mathrm{ml}$ のベンゼン**を用いて 抽出し, $10 \mathrm{ml}$ の水による洗浄を 2 回, $10 \%$ の炭 酸水素ナトリゥム溶液㧍よび水による洗浄をそれ ぞれ 1 回行なう。これら洗液は念のためにベンゼ ンでふたたび $\mathrm{N}-$ ニトロソアセトンリドー（フェ ニル- $\left.{ }^{14} \mathrm{C}\right)$ を抽出し，後処理ののち上記ベンゼン 溶液に加える。使用したベンゼンは全部で $100 \mathrm{ml}$ である。このベンゼン抽出液を常温で数日放置し て N-ニトロソアセトアニリド-(フェニル $\left.-{ }^{14} \mathrm{C}\right)$ の 分解を完全に行なわせ, 反応終結後水浴.上でベン ゼンを留去する。ここに得られたビフェニルー(フ ェニル $\left.-{ }^{14} \mathrm{C}\right)$ は石油エーテル***中に調製した径 $28 \mathrm{~mm}$, 長さ $180 \mathrm{~mm}$ の活性アルミナ柱を用い石 油エ゙ーテルを溶出液としてクロマトグラフ法で精 製する。上に留去したベンゼン中の微量のビフェ ニルー (フェニルー- $\left.{ }^{14} \mathrm{C}\right)$ を回収するために留出した ベンゼンに無標識ビフェニル**** $101.9 \mathrm{mg}$ を加 え同様な操作を行なう。得られたビフェニルー(フ ×ニル $\left.-{ }^{14} \mathrm{C}\right)$ は少量のエーテルで集め, のちエー テルを留去する。収量 $328.2 \mathrm{mg}$ 。のちに加えた 無標識ビフェニルはクロマトグラフ法の精製過程 で損失がないと仮定すればアセトアニリドー(フェ ニル $-{ }^{14} \mathrm{C}$ ) 以後の過程の収率は $26.7 \%$ となる(予 備実験ではニトロソ化 84\%，フェニル化 40\%)。

* $18.5 \mathrm{~g}$ の無水酢酸を含む大型試験管をドライアイ スーアルコール浴で泠却しながらこれに塩化ニトロ シルを送入， $6.5 \mathrm{~g}$ を溶解させる。前後の重さの差 より溶解した塩化ニトロシルの重量を知る。

**濃硫酸でチオフェンを除いたるのを蒸留精製し r。

*** 市販のものを蒸留し, $40 \sim 60^{\circ} \mathrm{C}$ の留分を用いる。 *****タノールで 3 回再結晶を繰り返乙厰点 70 〜 $71^{\circ} \mathrm{C}$ の の。 


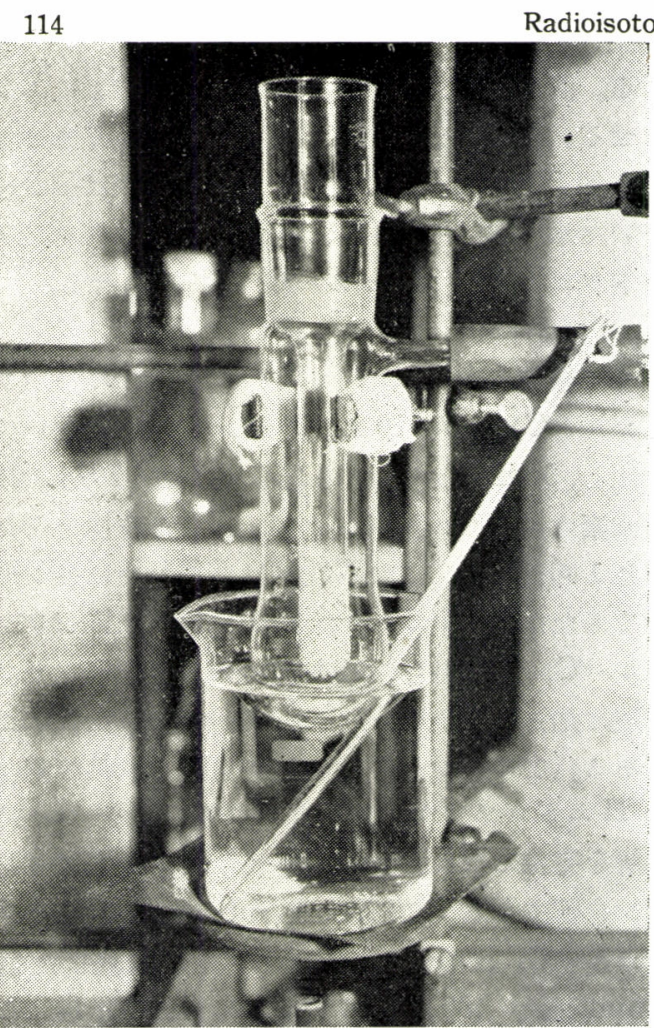

Fig. 2 Sublimation of Bipheny1- (phenyl-14 $\mathrm{C}$ ) これに無標識ビフェニル $333.9 \mathrm{mg}$ を加え $4 \sim 5$ $\mathrm{m} l$ のエーテルで第 2 図の昇華容器に移し, 容器 の底部索液体酸素で泠却し内部を減圧にしてから 徐々に常温にもどして溶媒を除く。溶媒がなくな ったら減圧にしながら中管をドライアイスーエタ ノールで泠却して昇華を繰り返す。昇華 4 回後の 収量 $564.2 \mathrm{mg}, 3.66 \mathrm{~m} \mathrm{~mol}$ 。その一部を無標識ビ
フェニルで希釈して 3 と同一の方法で比放射能を 測定した結果 $30.7 \pm 0.3 \mathrm{mc} / \mathrm{mol}$ であった。ゆえ にアセトアニリドー (フェニル $\left.-{ }^{14} \mathrm{C}\right)$ 以後の放射化 学的収率は $23.3 \%$ 。したがって全工程の收率およ び放射化学的收率はそれぞれ $15.8 \%$ 以上および 15.5\% である。

終わりにのぞみ終始ご指導をたまわった東京大 学島村修教授に深甚なる感謝の意を表する。

\section{文献}

1) J. P. Wibaut, H. M. Romijn and H. D. T. Willink: Rec. trav. chim., 53, 584 (1934).

2) P.E. Fanta: Chem. Rev., 38, 139 (1946).

3) M. S. Kharasch and E. K. Fields: J. Am. Chem. Soc., 63, 2316 (1941).

4) M. Gomberg and W. E. Bachmann: J. Am. Chem. Soc., 46, 2339 (1924).; J. Elks, J. W. Haworth and D. H. Hey: J.Chem. Soc., 1284 (1940).

5) E. F. Jenny and J. D. Roberts: Helv. Chim. Acta, 38,1248 (1955).

6) 森川倚威, 伊藤良一, 右田俊彥, 丹野毅, 島村修, Radioisotopes, 8, 246 (1959).

7) 日本化学会編：実験化学講座 17 有機化学反応 I (下) p. 307 丸善 KK (1956).; H. Adkins and H. R. Billica: J. Am. Chem. Soc., 70, 695 (1948).; "Organic Syntheses", Coll. Vol. III, p.176 New York, John, Wiley \& Sons, Inc., (1955).

8) D. D. Van Slyke and J.Folch: J. Biol. Chem., 136, 509 (1940). 


\title{
Synthesis of Biphenyl-(phenyl- $\left.{ }^{14} \mathrm{C}\right)$
}

\author{
By \\ Hiroaki KŌYAMA*, Naotake MORIKAWA**, Toshihiko MIGITA**, \\ Ryōichi I'TŌ** and Gen-ichi 'TSUCHIHASHI* \\ (*Radiation Application Division, Japan Atomic Energy Research Institute; \\ **Department of Chemistry, Faculty of Science, University of Tokyo)
}

(Received April 22, 1960)

Biphenyl- (phenyl- ${ }^{14} \mathrm{C}$ ) was prepared from benzene-1-14 $\mathrm{C}$ according to the following process:

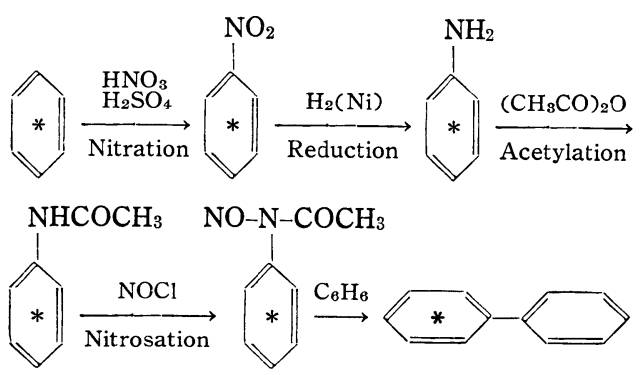

In advance of the radioactive procedure, the preliminary test was carried out with non-labelled compounds in the same scale.

A mixture of nitric acid $(\mathrm{d}=1.38,1.0 \mathrm{~g})$ and sulfuric acid $(\mathrm{d}=1.85,1.3 \mathrm{~g})$ was added to benzene- $1-{ }^{14} \mathrm{C}(1.0 \mathrm{mc}, 5 \mathrm{~m} \mathrm{~mol})$ at $50^{\circ} \mathrm{C}$ and the mixture was kept at $50^{\circ} \sim 60^{\circ} \mathrm{C}$ for 50 mins. with shaking. After being cooled, it was neutralized with aqueous sodium carbonate $(20 \%, 9 \mathrm{~g})$ and steam-distilled. The distillate was extracted with ether (Soxhlet) and the ether was removed.

Nitrobenzene- ${ }^{14} \mathrm{C}$ was reduced with hydrogen on Raney nickel $(2 \mathrm{ml})$ in ethanol. After being reduced, the reaction mixture was extracted with ethanol (Soxhlet).
Aniline $-{ }^{14} \mathrm{C}$ was acetylated with acetic anhydride $(1.1 \mathrm{~g})$ in ethanol. Evaporation of the solvent and chromatography of the residue on activated alumina with ether gave acetanilide- $($ phenyl--14 $\mathrm{C})(87.7 \pm 0.9 \mathrm{mc} / \mathrm{mol}, 7.61 \mathrm{~m}$ mol).

Potassium acetate $(1.9 \mathrm{~g})$, acetic acid-acetic anhydride solution $(7: 3,3.4 \mathrm{~m} l)$ and a little of phosphorus pentoxide were added to acetanilide-(phenyl- $\left.{ }^{14} \mathrm{C}\right) \quad(742.4 \mathrm{mg}, 5.50 \mathrm{~m} \mathrm{~mol})$ with stirring and the mixture was cooled witir ice. Cooled nitrosyl chloride-acetic acid solution $(26 \%, 2.2 \mathrm{ml})$ was added dropwise to the above mixture with stirring in ice and kept at the ice temperature for 30 mins. Pouring the: reaction mixture into ice $(25 \mathrm{~g})$ gave the pale yellow product.

$\mathrm{N}$-nitrosoacetanilide- ( henyl-1! $\mathrm{C}$ ) was extracted $\mathrm{w}^{\mathrm{t}} \mathrm{th}$ benzene $(70 \mathrm{ml})$ from the above mixture and the extract was washed with water and sodium hydrogen carbonate (10\%) and kept at room temperature for several days. Removal of the benzene, chromatography of the residue on activated alumina with petroleum ether and several times of sublimation afforded biphenyl- (phenyl- ${ }^{14} \mathrm{C}$ ) $(30.6 \pm 0.3 \mathrm{mc} / \mathrm{mol}, 3.66 \mathrm{~m} \mathrm{~mol})$. 
In order to avoid the loss of ${ }^{14} \mathrm{C}$-labelled compounds and to dilute to the desired radioactive concentration, non-labelled compounds were added to the system and the same procedure was repeated at several stages. The overall radiochemical yield from benzene- $1-{ }^{14} \mathrm{C}$ was $15.5 \%$. 